\title{
Design of Stocking Density of Broilers for Closed House in Wet Tropical Climates
}

\author{
A. Yani ${ }^{\mathrm{a},{ }^{,},}$, H. Suhardiyanto ${ }^{\mathrm{b}, \sharp}$, Erizal $^{\mathrm{c}, \sharp}$, \& B. P. Purwanto ${ }^{\mathrm{d}}$ \\ aStudy Program of Agricultural Engineering, Graduate School, Bogor Agricultural University \\ Gedung Andi Hakim Nasoetion, Kampus IPB Darmaga Bogor 16680, Indonesia \\ ${ }^{b}$ Department of Mechanical and Biosystem Engineering, Faculty of Agricultural Engineering, \\ Bogor Agricultural University \\ 'Department of Civil and Environmental Engineering, Faculty of Agricultural Engineering, \\ Bogor Agricultural University \\ "Kampus IPB Darmaga, Bogor 16002, Indonesia \\ dDirectorate of Diploma Program, Bogor Agricultural University \\ Jln. Kumbang No. 14, Kampus IPB Cilibende Bogor 16151, Indonesia \\ (Received 02-03-2014; Reviewed 11-03-2014; Accepted 05-04-2014)
}

\begin{abstract}
The objectives of this research were to: 1 ) design the stocking density of broiler reared at a closed house system in wet tropical climates based on the heat released by broiler, 2) design broiler harvesting system based on the housing heat load, and 3) design required housing area based on the broiler age. The housing design used to determine the broiler stocking density was based on Computational Fluid Dynamics (CFD) with Solid Works Flow Simulation software. The method had good validation shown by small number of average percentage of deviation $(6.07 \%)$. Simulation was carried out by changing the number of broilers i.e. 16, 18, 20, 21 and $22 \mathrm{birds} / \mathrm{m}^{2}$. According to the CFD simulation result, total heat load inside the house was $233.33 \mathrm{~kW}$ at $21 \mathrm{birds} / \mathrm{m}^{2}$ at weight 1.65 $\mathrm{kg} / \mathrm{bird}$. At that stocking density the housing can be occupied by 27,224 birds until 22 days of age. The highest total weight was produced by daily harvesting started from 22 to $32 \mathrm{~d}$. It can be concluded that the stocking density of closed house for broiler is $34.65 \mathrm{~kg} / \mathrm{m}^{2}$, total production is $45,717 \mathrm{~kg}$ per period and the required area for 27,224 broilers is $248.63 \mathrm{~m}^{2}$ ( 1 to 7 days of age broiler), $562.52 \mathrm{~m}^{2}$ ( 8 to 14 days of age broiler) and $1,000 \mathrm{~m}^{2}$ (15 to 22 days of age broiler).
\end{abstract}

Key words: broiler, computational fluid dynamics, stocking density, total heat

\section{ABSTRAK}

Penelitian ini bertujuan mendesain kepadatan ayam broiler pada kandang sistem tertutup di daerah beriklim tropika basah berdasarkan panas yang dikeluarkan ayam broiler, mendesain pemanenan ayam broiler berdasarkan beban panas kandang dan mendesain kebutuhan luas kandang menurut umur ayam. Desain kandang yang digunakan untuk menentukan kepadatan ayam broiler pada Computational Fluid Dyanamics (CFD) dengan software Solidworks Flow Simulation memiliki tingkat validasi cukup baik dengan nilai rataan persentase deviasi cukup rendah $(6,07 \%)$. Simulasi dilakukan pada saat ayam broiler mendekati panen (umur 30 hari, bobot 1,65 kg) dengan cara mengubah jumlah ayam broiler yaitu 16, 18, 20, 21, dan $22 \mathrm{ekor} / \mathrm{m}^{2}$. Berdasarkan hasil simulasi menggunakan CFD (luas kandang $1.000 \mathrm{~m}^{2}$ ) diperoleh total panas ayam broiler sebesar 233,33 KW dengan kepadatan $21 \mathrm{ekor} / \mathrm{m}^{2}$ pada bobot badan 1,65 kg/ekor. Pada tingkat kepadatan tersebut, sampai umur 22 hari dapat diisi 27.224 ekor ayam broiler dan menghasilkan total bobot panen tertinggi apabila dipanen setiap hari dari umur 22 sampai 32 hari. Dengan demikian diperoleh tingkat kepadatan ayam broiler $34,65 \mathrm{~kg} / \mathrm{m}^{2}$, total bobot panen $45.717 \mathrm{~kg}$ dan luas kandang yang dibutuhkan adalah 248,63 $\mathrm{m}^{2}$ (umur ayam 1 sampai 7 hari), 562,52 $\mathrm{m}^{2}$ (umur ayam 8 sampai 14 hari) dan $1.000 \mathrm{~m}^{2}$ (umur ayam 15 sampai 22 hari).

Kata kunci: broiler, computational fluid dynamics, kepadatan, panas total

${ }^{*}$ Corresponding author:

E-mail: a_yanicirebon@yahoo.co.id 


\section{INTRODUCTION}

Some efforts could be implemented to increase the productivity of broiler chicken reared in a closed house system. Some of those are feed management, disease prevention and treatment, in-house micro environmental control including temperature, air velocity and relative humidity, and also stocking density designed based on the broiler's age and body weight (North \& Bell, 1990). Stocking density design of a closed house system may affect the placement position of feeding and drinkers' line, number of feeding and drinkers set, control panel of temperature and relative humidity which in certain condition could make some difficulties to broiler-breeder.

Stocking density rate in a closed house system applied by broilers holders may vary across countries as they design based on the regular practice, recommendation from business partners and literature references (Buijs et al., 2009). A closed house system could occupy 12 to 16 birds $/ \mathrm{m}^{2}$. In a particular condition such as too high stocking density rate, broiler holders will do early harvesting at 22 to 24 days of age. However, the stocking density of broiler depends on the age or body weight. In addition, a closed house system with favorable housing micro environment could occupy 16 to $20 \mathrm{birds} / \mathrm{m}^{2}$ or 30 to $36 \mathrm{~kg} / \mathrm{m}^{2}$ (North \& Bell, 1990; Yardimci \& Kenar, 2008; Abudabos et al., 2012; Abudabos et al., 2013).

It was reported that the increasing of broiler's stocking density in a closed house system could give some effects. Some of those were reducing feed intake, reducing feed efficiency, reducing broiler growth performance, increasing mortality and cannibalism, and increasing ventilation equipment (North \& Bell, 1990), and increasing number of microbes found in litter (Yardimci \& Kenar, 2008), reducing weight of lymphoid and increasing concentration of corticosterone in the serum (QuinteiroFilho et al., 2010), reducing broiler performance and welfare (Abudabos et al., 2012; Abudabos et al., 2013). The important condition should be noticed that the increasing stocking density rate could increase the thermal heat load due to the accumulation of broiler's heat released into housing environment. This condition causes stress on broiler thus reduce growth rate (Sugito et al., 2007; Kusnadi \& Rahim, 2009).

Total heat released per unit weight of broilers decreases in conjunction with the increases of age and weight, but it increases at each of broiler due to an increase on the body weight which then contributes to the increasing of total heat inside the house (Cordeau \& Barrington, 2010). Thus, calculation on the maximum total heat inside the house should be conducted to provide comfort environment for flocks. This calculation results the maximum stocking density rate in which the in-house environment condition is still comfort, number of broilers which can be harvested on schedule, and total of space area required by different age and weight.

Computational Fluid Dynamics (CFD) based on two or three dimensional numeric analysis through integration equation of mass, momentum and energy was applied in this research to calculate the maximum heat load occurred at broiler's closed house system in wet tropical climates (Versteeg \& Malalasekera, 1995).
In this research, CFD was used to model the geometry, the thermo physical properties and the total heat of heat sources occurred at experimental closed house which include plafond, rice husk, curtain, cooling pad, fan and broiler chicken itself. The objectives of this research were to: 1) design the stocking density of broiler at closed house system in wet tropical climates based on the heat released by broiler and micro environmental condition, 2) design harvesting system of broiler chicken based on the total heat load occurred at the house, 3) design housing area based on the broiler age or rearing period.

\section{MATERIALS AND METHODS}

The research was carried out in a closed house system for broiler at the Faculty of Animal Science, Bogor Agricultural University from May to July 2013. The dimension of the experimental house was $100 \mathrm{~m}$ length $\times 10 \mathrm{~m}$ width $\times 2.4 \mathrm{~m}$ height occupied with 9.656 broilers chicken. The floor was made from concrete cement with rice husk placed on, the stud was made of iron material, the wall was made of expose mercy brick to support the curtain, the plafond was made of galvaniz, the ventilation system consisted of 6 fans with $1.27 \mathrm{~m}$ in diameter, in-house lighting consisted of 60 units of 8 watt bulb lamp, and cooling pad was set up to reduce the in-house temperature.

The tools used in the experiment were portable paperless recorder (Yokogawa, MV Advance 1000), anemometer, lux meter to measure micro environmental condition inside the house, personal computer, caliper, weighing scale and infrared thermography with $2 \%$ precision level and spectral ranges from 7.5 to $13 \mu \mathrm{m}$ to measure the body surface temperature of broiler chicken (head, leg and body). The capture distance between broiler and camera was $2 \mathrm{~m}$, emissivity was set at 0.95 and temperature ranged from $30{ }^{\circ} \mathrm{C}$ to $45{ }^{\circ} \mathrm{C}$. The temperature of body surface was measured when the housing temperature was fairly high, i.e. $32.5^{\circ} \mathrm{C}$ with relative humidity was $71 \%$. This environment condition was designed for broiler to release maximum heat. Micro environment data, such as air temperature and relative humidity (inside and outside), wind speed, air velocity, temperature of husk, plafond, curtain, litter, were measured and recorded with interval $30 \mathrm{~min}$ started from 06:00 to 18:00 during one breeding period (35 d).

In this experiment ThermaCAM Researcher Professional and CFD with Solid Works Flow Simulation software were used to analyze data. Data measurement from infrared thermography was used to analyze the body surface temperature of broiler using ThermaCAM Researcher Professional software. CFD with Solid Works Flow Simulation software used to determine the stocking density of broiler in the experimental house showed good validation with small number of average percentage of deviation $(2.18 \%)$. Thus, determination of material and boundary condition of CFD was appropriate and could present real house condition. Environment data from measurement on June 29 2013 at 13:00 (1 pm) were selected as representing sunny day which heat load of closed house reached maximum. In accordance with the measurement, the micro environment condition 
outside the house was 808 Watt $/ \mathrm{m}^{2}, 34.3{ }^{\circ} \mathrm{C}, 57 \%$ and 1,027.5 Bar for radiation intensity, temperature, relative humidity and air pressure, respectively. While the micro environment condition inside the house was 54.09, 32.54, $27.41,30.88,34.93$, and $34.95^{\circ} \mathrm{C}$ for roof temperature, soil temperature at $0.2 \mathrm{~m}$ depth, water temperature of cooling pad, rice husk temperature, plafond temperature and curtain temperature, respectively. The environment conditions both inside and outside closed house showed the maximum heat load in region of wet tropical climate. The maximum heat load is critical condition to design of stocking density broilers for closed house.

\section{Convection Coefficient of Broiler Chicken}

Birds release heat through head, leg, and body thus it analogue as radiator in designing the stocking density of broiler house (Yani et al., 2007). Heat is released through radiation, convection, and conduction where the highest amount occurs by convection and radiation. Total heat released from the whole body of bird has to be taken into consideration in designing closed house system in wet tropical climates. Heat transfer coefficient of convection (h) of birds was calculated from equation developed by Yahav et al. (2004) and Van Brecht et al. (2005) as follow:

$$
\begin{aligned}
& Q_{T}=Q_{R}+Q_{C} \ldots . \\
& Q_{R}=e \sigma A\left(T_{s}^{4}-T_{\infty}^{4}\right) . . \\
& Q_{C}=h A\left(T_{s}-T_{\infty}\right) \ldots \ldots . \\
& h=\frac{Q_{T}-Q_{R}}{A\left(T_{s}-T_{\infty}\right)} \ldots .
\end{aligned}
$$

where $Q_{T}=$ total heat released by birds (Watt), $Q_{R}=$ heat loss by radiation (Watt), $\mathrm{Q}_{\mathrm{C}}=$ heat loss by convection (Watt), $\mathrm{e}=$ bird emissivity (0.95), $\sigma=$ Stefan-Boltzman constant $\left(5.67 \times 10-8 \mathrm{Watt} / \mathrm{m}^{2} /{ }^{\circ} \mathrm{K}^{4}\right), \mathrm{h}=$ heat transfer coefficient of convection (Watt $/ \mathrm{m}^{2} /{ }^{\circ} \mathrm{C}$ ), $\mathrm{A}=$ bird surface area $\left(\mathrm{m}^{2}\right)$, Ts $=$ bird surface temperature $\left({ }^{\circ} \mathrm{C}\right), \mathrm{T} \infty=$ housing temperature $\left({ }^{\circ} \mathrm{C}\right)$. The total broiler surface area was calculated using this following equation (Yanagi et. al., 2001):

$$
A=0.1067 \times \mathrm{m}^{0,705}
$$

where $A=$ bird surface area $\left(\mathrm{m}^{2}\right)$ and $\mathrm{m}=$ bird weight (kg).

\section{Computational Fluid Dynamics (CFD)}

Computational Fluid Dynamics (CFD) could be used to design the stocking density rate of a closed house designed for broiler in wet tropical climates as CFD operated on the basis on numeric analysis of volume control which deals with the equation integration that represented three balance process of mass, momentum and energy. Thus, the equation of two or three dimensional could be derived faster and simultaneously (Versteeg \& Malalasekera 1995). The principal work of CFD is designed by modeling the condition of a closed house comprising the geometry, material of the building, thermo physical properties of the building, heat source and the amount of heat source, environment condition affecting the heat and energy balance, and heat amount released by the material of the building.

Computational Fluid Dynamics (CFD) consisted of three main elements, i.e. pre-processor, solver and post-processor. The activities at pre-processor were: 1) defining the geometry of the region; 2) mesh generation at each domain; 3) selection of required physical and chemical phenomena; 4) definition of conductivity, viscosity, specific heat, and density; 5) specification of appropriate boundary condition (Versteeg \& Malalasekera, 1995). The activities at solver were: 1) approximation of the unknown fluid flow using simple equation; 2) discretization; 3) solution of the algebraic equation. In solver computation, there are three streams of fluid i.e. conservation law of mass fluid, Newton's second law and the First Law of Thermodynamic. The result of preprocessor and solver was then displayed in post-processor in the form of domain geometry and grid display, vector plot, two or three dimensional surface plots, air temperature and flow rate, particle movement and color output.

\section{Stocking Density Simulation of Broiler's Closed House}

CFD simulation to determine the stocking density inside the house was performed by alternating the number of broilers of 16, 18, 20, 21, and 22 birds $/ \mathrm{m}^{2}$ (North \& Bell, 1990; Yardimci \& Kenar, 2008; Abudabos et al., 2012; Abudabos et al., 2013). Simulation was designed using broiler which closed to the harvesting age at 30 days with average weight of $1.65 \mathrm{~kg}$. This experimental condition was designed to obtain sufficient heat inside the house as the bird at this age releases the highest amount of heat. The maximum housing air velocity was generated from 6 units of fan with $69.948 \mathrm{~m} 3 \mathrm{~s}-1$ and cross-sectional area of $24 \mathrm{~m} 2$. This number of air velocity was considered to be in the range of comfort zone (Donald, 2010).

Housing temperature obtained from simulation was the average temperature occurred inside the house. Taken together with air flow rate of $2.92 \mathrm{~ms}^{-1}$, effective temperature was obtained in order to determine the comfort zone at simulated stocking density. The temperature of cooling pad was set at the lowest daily comfortable temperature occurred inside the house, i.e. $22.5^{\circ} \mathrm{C}$ (Pereira \& Naas, 2008).

In this research, underlying assumptions used to determine the stocking density of broiler reared in a closed house system were: 1) air inside the house was incompressible; 2) fan speed was assumed constant during simulation; 3) specific heat, conductivity, and viscosity of air were constant (Prandtl number of air was constant); 4) temperature of rice husk was uniform in accordance to the boundary condition; 5) temperature of plafond was uniform in accordance to the boundary condition; 6) temperature of curtain was uniform in accordance to the boundary condition; 7) temperature of light bulb was uniform in accordance to the boundary 
condition; and 8) temperature of roof did not affect the boundary condition of plafond's temperature.

\section{RESULTS AND DISCUSSION}

Broiler stocking density in a closed house system was determined by the micro environmental condition such as air temperature, relative humidity and solar radiation (micro environment outside the house), water temperature of cooling pad, air flow rate inside the house, relative humidity inside the house, plafond temperature, curtain temperature, wall temperature, rice husk temperature (micro environment inside the house), and broiler surface temperature as heat source (radiator). As a heat source, broiler releases sensible and insensible heat (North \& Bell, 1990). The amount of heat released at each part of broiler was closely related to surface temperature presented in Figure 1. Temperature of leg was higher than body and head. Surface temperature at body featherless area was higher than those which covered by feather (Naas et al., 2010). According to the result of measurement and calculation using Solid Works Flow Simulation software, surface area which covered by feather was $68.42 \%$ and others which were

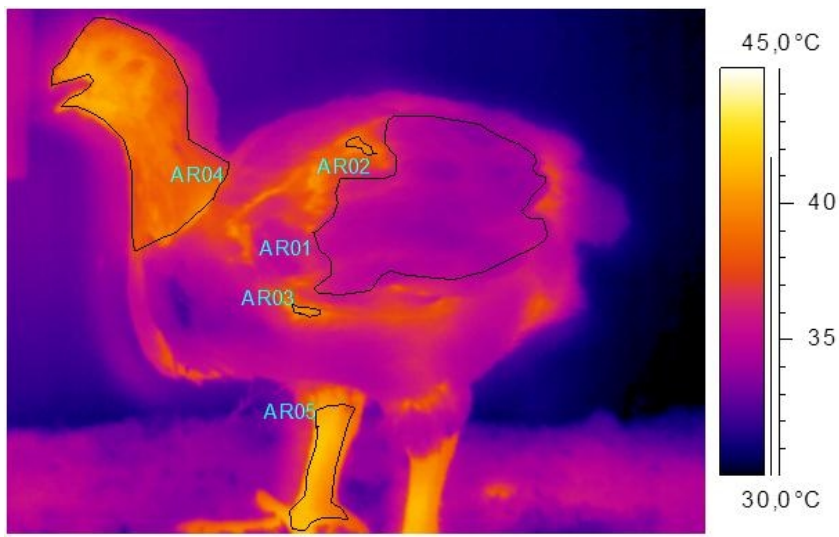

Figure 1. Surface temperature profile of broiler resulted from measurement using infrared thermography not covered was $31.58 \%$. The surface area of body, leg and head was basically computed by the weight of body $(1.477 \mathrm{~kg})$, head $(0.119 \mathrm{~kg})$ and leg $(0.054 \mathrm{~kg})$.

The surface temperature of broiler which used as input data in CFD simulation was the temperature at the highest heat loss by broiler. In other words, if broiler released lower temperature then the stocking density design was more favorable for broiler providing more comfortable environment. In this simulation, broiler was considered as a modeled like radiator which releases heat continuously throughout the head, body and leg. Thus, broiler was a new material in the SolidWorks Flow Simulation software. According to the measurement, calculation and analysis, the properties and input of CFD program are shown in Table 1.

Standing position of the bird was used to simulate CFD using Solid Works Flow Simulation. The distance of leg, body and head from rice husk (litter) was 0 to $0.07 \mathrm{~m}, 0.07$ to $0.15 \mathrm{~m}$, and 0.15 to $0.21 \mathrm{~m}$, respectively. Broiler body parts such as leg, body and head were horizontally overlaid in a closed house system where the occupied area was associated with the housing stocking density with $1,000 \mathrm{~m}^{2}$. The position of each body parts of broiler at closed house simulated using CFD is shown in Figure 2.

According to the simulation resulted from CFD, increasing of stocking density increased the effective

Table 1. Body weight, surface area and temperature, sensible heat and heat transfer coefficient of each bird

\begin{tabular}{lrrrr}
\hline \multicolumn{1}{c}{ Component } & $\begin{array}{c}\text { Body } \\
\text { featherless } \\
\text { area }\end{array}$ & $\begin{array}{c}\text { Body } \\
\text { covered } \\
\text { by feather }\end{array}$ & Head & Leg \\
\hline Area $\left(\mathrm{m}^{2}\right)$ & 0.0491 & 0.1063 & 0.0081 & 0.0014 \\
Temperature $\left({ }^{\circ} \mathrm{C}\right)$ & 39.5000 & 34.7000 & 38.8000 & 40.6000 \\
Sensible heat $(\mathrm{Watt})$ & 3.1400 & 6.8051 & 0.8014 & 0.3636 \\
$\begin{array}{l}\text { Heat transfer } \\
\text { coefficient of } \\
\text { convection }\left(\mathrm{W} / \mathrm{m}^{2}{ }^{\circ} \mathrm{C}\right)\end{array}$ & 9.1368 & 29.0959 & 15.6936 & 32.7582 \\
\hline
\end{tabular}

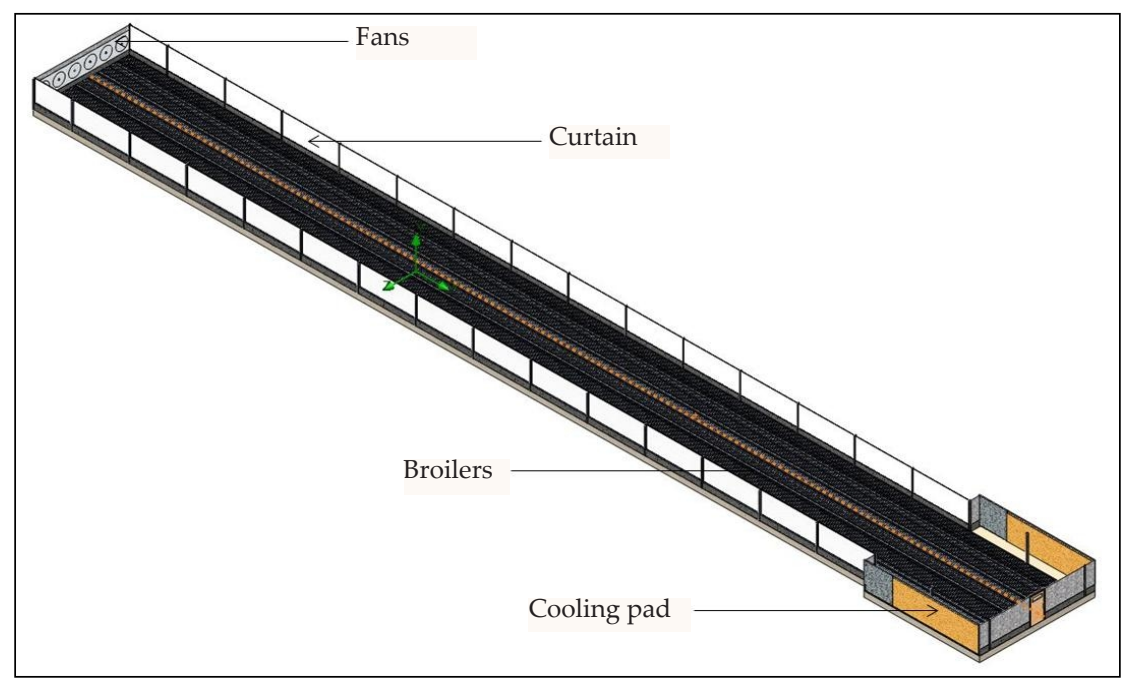

Figure 2. The geometry of experimental house and position of each parts used for Computational Fluid Dynamics (CFD) simulation 
temperature inside the house (Table 2) due to the accumulation of total heat released by broiler. The highest amount of heat accumulated at the house was obtained when the effective temperature closed to or not higher than $24.5{ }^{\circ} \mathrm{C}$ which was still comfortable for broiler (Donald, 2010). The optimum condition for relative growth rate of live weight for broilers was $20-24{ }^{\circ} \mathrm{C}$ at finisher phase (Herawati \& Adiwinarto, 2012). The effective temperature was obtained at stocking density of 21 birds $/ \mathrm{m}^{2}\left(34.65 \mathrm{~kg} / \mathrm{m}^{2}\right)$ with total heat inside the house was $233.33 \mathrm{KW}$ (Table 3). This finding was higher than those suggested by North \& Bell (1990) of $30.4 \mathrm{~kg} / \mathrm{m}^{2}$, by Abudabos et al. (2012) of $31.8 \mathrm{~kg} / \mathrm{m}^{2}$ and by Yardimci \& Kenar (2008) of $33 \mathrm{~kg} / \mathrm{m}^{2}$.

Maximum total heat inside the house resulted from CFD simulation i.e. $233.33 \mathrm{KW}$ was used to determine number of broiler based on the age, harvesting schedule, number of broiler that could be harvested on schedule, optimum bird weight at harvest, and housing area based on the bird age. According to the age and weight, maximum number of broiler inside the house was 27,224 calculated from maximum heat during the first early harvesting of $22 \mathrm{~d}$ (Table 4 ). Total number of broiler at

Table 2. Stocking density resulted from Computational Fluid Dynamics (CFD) simulation

\begin{tabular}{cccc}
\hline $\begin{array}{c}\text { Simulation } \\
\left(\text { birds } / \mathrm{m}^{2}\right)\end{array}$ & $\begin{array}{c}\text { Body } \\
\text { weight } \\
\left(\mathrm{kg} / \mathrm{m}^{2}\right)\end{array}$ & $\begin{array}{c}\text { Total heat inside } \\
\text { the house } \\
\left(\text { Watt } / \mathrm{m}^{2}\right)\end{array}$ & $\begin{array}{c}\text { Effective } \\
\text { temperature inside } \\
\text { the house }\left({ }^{\circ} \mathrm{C}\right)\end{array}$ \\
\hline 16 & 26.40 & 117.78 & 22.876 \\
18 & 29.70 & 200.00 & 23.931 \\
20 & 33.00 & 222.22 & 24.240 \\
21 & 34.65 & 233.33 & 24.397 \\
22 & 36.30 & 244.44 & 24.505 \\
\hline
\end{tabular}

Table 3. Number of broiler occupied at a closed house system based on heat load in accordance with broiler age

\begin{tabular}{|c|c|c|c|c|c|c|c|}
\hline $\begin{array}{l}\text { Broiler age } \\
\text { (day) }\end{array}$ & $\begin{array}{l}\text { Weight per bird } \\
(\mathrm{kg})^{1}\end{array}$ & $\begin{array}{l}\text { Total heat loss of } \\
\text { broiler (Watt } / \mathrm{kg} \text { ) }\end{array}$ & $\begin{array}{l}\text { Total heat loss } \\
\text { per bird (Watt) }\end{array}$ & $\begin{array}{l}\text { Maximum total } \\
\text { heat loss }(\mathrm{KW})\end{array}$ & $\begin{array}{c}\text { Number of } \\
\text { broiler (birds) }\end{array}$ & $\begin{array}{c}\text { Dead off grade } \\
\text { broiler }\end{array}$ & $\begin{array}{c}\text { Total } \\
\text { broiler }\end{array}$ \\
\hline 1 & 0.057 & 10.940 & 0.624 & 233.333 & 27,566 & 17 & 27,584 \\
\hline 2 & 0.075 & 10.892 & 0.817 & 233.333 & 27,549 & 17 & 27,566 \\
\hline 3 & 0.096 & 10.837 & 1.040 & 233.333 & 27,532 & 17 & 27,549 \\
\hline 4 & 0.118 & 10.778 & 1.272 & 233.333 & 27,515 & 17 & 27,532 \\
\hline 5 & 0.143 & 10.712 & 1.532 & 233.333 & 27,498 & 17 & 27,515 \\
\hline 6 & 0.170 & 10.641 & 1.809 & 233.333 & 27,480 & 17 & 27,498 \\
\hline 7 & 0.200 & 10.562 & 2.112 & 233.333 & 27,463 & 17 & 27,480 \\
\hline 8 & 0.232 & 10.478 & 2.431 & 233.333 & 27,446 & 17 & 27,463 \\
\hline 9 & 0.267 & 10.385 & 2.773 & 233.333 & 27,429 & 17 & 27,446 \\
\hline 10 & 0.306 & 10.282 & 3.146 & 233.333 & 27,412 & 17 & 27,429 \\
\hline 11 & 0.348 & 10.171 & 3.540 & 233.333 & 27,395 & 17 & 27,412 \\
\hline 12 & 0.391 & 10.058 & 3.933 & 233.333 & 27,378 & 17 & 27,395 \\
\hline 13 & 0.438 & 9.934 & 4.351 & 233.333 & 27,360 & 17 & 27,378 \\
\hline 14 & 0.490 & 9.796 & 4.800 & 233.333 & 27,343 & 17 & 27,360 \\
\hline 15 & 0.547 & 9.646 & 5.276 & 233.333 & 27,326 & 17 & 27,343 \\
\hline 16 & 0.609 & 9.482 & 5.775 & 233.333 & 27,309 & 17 & 27,326 \\
\hline 17 & 0.674 & 9.311 & 6.275 & 233.333 & 27,292 & 17 & 27,309 \\
\hline 18 & 0.741 & 9.134 & 6.768 & 233.333 & 27,275 & 17 & 27,292 \\
\hline 19 & 0.810 & 8.952 & 7.251 & 233.333 & 27,258 & 17 & 27,275 \\
\hline 20 & 0.880 & 8.767 & 7.715 & 233.333 & 27,241 & 17 & 27,258 \\
\hline 21 & 0.950 & 8.582 & 8.153 & 233.333 & 27,224 & 17 & 27,241 \\
\hline 22 & 1.021 & 8.395 & 8.571 & 233.333 & 27,224 & 17 & 27,241 \\
\hline 23 & 1.093 & 8.204 & 8.967 & 233.333 & 26,003 & 16 & 26,019 \\
\hline 24 & 1.167 & 8.009 & 9.347 & 233.333 & 24,948 & 16 & 24,964 \\
\hline 25 & 1.242 & 7.811 & 9.701 & 233.333 & 24,036 & 15 & 24,051 \\
\hline 26 & 1.320 & 7.605 & 10.039 & 233.333 & 23,228 & 15 & 23,242 \\
\hline 27 & 1.399 & 7.397 & 10.348 & 233.333 & 22,534 & 14 & 22,548 \\
\hline 28 & 1.480 & 7.183 & 10.631 & 233.333 & 21,935 & 14 & 21,949 \\
\hline 29 & 1.563 & 6.964 & 10.884 & 233.333 & 21,424 & 13 & 21,437 \\
\hline 30 & 1.646 & 6.745 & 11.102 & 233.333 & 21,005 & 13 & 21,018 \\
\hline 31 & 1.731 & 6.520 & 11.286 & 233.333 & 20,661 & 13 & 20,674 \\
\hline 32 & 1.817 & 6.293 & 11.435 & 233.333 & 20,393 & 13 & 20,406 \\
\hline
\end{tabular}

Note: ${ }^{1)}$ Production target 


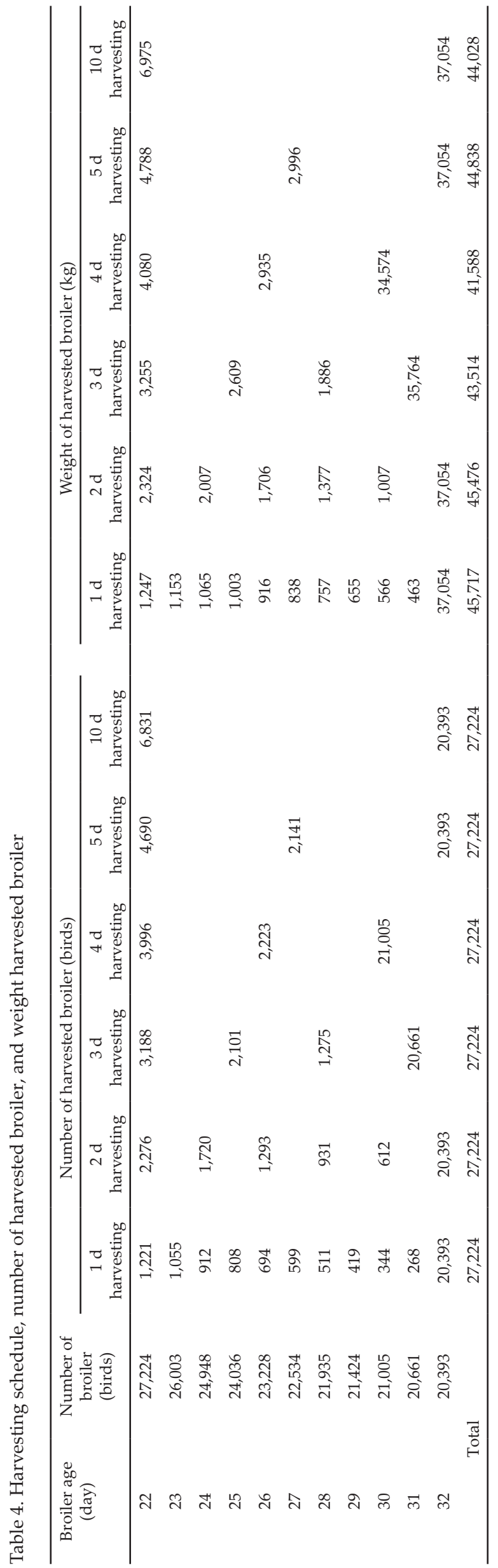

1 to 22 days of age was relatively similar as the absence of early harvesting and added with $2 \%$ of mortality risk (North \& Bell, 1990) during rearing period which meant that there were always dead or off-grade birds every day. Number of broiler at 22 to 32 days of age tends to decrease due to the increasing of body weight (total heat released by broiler also increased).

Determination of the number of harvested broilers was calculated from excess heat released by broiler thus harvesting could be carried out daily, every two days, three days, four days, five days or only twice, i.e. at 22 $\mathrm{d}$ (early harvesting) and $32 \mathrm{~d}$ (peak harvesting). Number of total harvested broiler per house was similar $(27,224$ birds) for every harvesting schedule (daily, every two days and so on). However, it produced different total weight at each different harvesting schedule (Table 4). The highest weight was $45,717 \mathrm{~kg}$ which produced by daily harvesting started from 22 to $32 \mathrm{~d}$. Meanwhile, the lowest was $41,588 \mathrm{~kg}$ which produced by harvesting schedule per four days. Thus, the difference was 4,129 $\mathrm{kg}$. Breeders usually harvested twice: early harvesting at 22 days of age and peak harvesting at 32 days of age. This scenario produced $44,028 \mathrm{~kg}$ which was fewer than daily harvesting scenario $(45,717 \mathrm{~kg})$.

Breeders have different perspectives in determining the housing area required for one breeding period where harvesting is carried out based on the total heat load. Prior to the first harvesting age (22 d), a broiler chick requires small area which were $248.63 \mathrm{~m}^{2}(24.86 \%)$ for 27,224 broilers with 1 to 7 days of age, $562.52 \mathrm{~m} 2$ (56.25\%) for 8 to 14 days of age, and 1,000 m2 (100\%) for broiler with 22 to 32 days of age. For the shake of efficiency, two or three houses recommended to be built in one breeding period. Under this scenario, broilers could be replaced from one house to the other thus empty house could be used on the next period of rearing. This condition could increase the number of broiler breeding period from 6 to 7 times to 12 to 14 times in a year for two houses scenario and 18 to 21 times in a year for three houses scenario.

\section{CONCLUSION}

Number of broiler that can be placed in the experimental house of $100 \mathrm{~m}$ length $\mathrm{x} 10 \mathrm{~m}$ width $\mathrm{x}$ $2.4 \mathrm{~m}$ height is 27,224 birds with the highest weight of $45,717 \mathrm{~kg}$ harvested daily started from 22 to $32 \mathrm{~d}$. It is suggested that the housing area for 27,224 birds is 248.63 $\mathrm{m}^{2}$ for broiler at 1 to 7 days of age, $562.52 \mathrm{~m}^{2}$ for 8 to 14 days of age, and $1,000 \mathrm{~m}^{2}$ for broiler with 15 to 22 days of age.

\section{REFERENCES}

Abudabos, A. M., M. M. Abdelrahman, H. M. Yehia, M. Q. Al-Ghadi, \& I. A. Alhidary. 2013. Effect of stocking density on intestinal histology and ileal bacterial count in broilers. Asian J Anim Vet Adv. 8: 740-746. http://dx.doi. org/10.3923/ajava.2013.740.746

Abudabos, A. M., E. M. Samara, E. O. S. Hussein, M. Q. AlGhadi, \& R. M. Al-Atiyat. 2012. Impacts of stocking density on the performance and welfare of broiler chickens. It J Anim Sci. 12:e11. http://dx.doi.org/10.4081/ijas.2013.e11 
Buijs, S., L. Keeling, S. Rettenbacher, E. Van Poucke, \& F.A.M. Tuyttens. 2009. Stocking density effects on broiler welfare: Identifying sensitive ranges for different indicators. Poultry Sci. 88: 1536-1543. http://dx.doi.org/10.3382/ps.200900007

Cordeau, S. \& S. Barrington. 2010. Heat balance for two commercial broiler barns with solar preheated ventilation air. J. Biosyst Eng. 107: 232 - 241. http://dx.doi.org/10.1016/j.bi osystemseng.2010.08.007

Donald, J.O. 2010. Environmental Management in the Broiler House. http://www.aviagen.com. [28 January 2014].

Herawati \& G. Adiwinarto. 2012. Effective temperature at finisher phase to promote relative growth rate of broiler strain cob. Int. J. Poult. Sci. 11: 644-648. http://dx.doi.org/10.3923/ ijps.2012.644.648

Kusnadi, E. \& F. Rahim. 2009. Performance and plasma triiodothyronine of broilers as result effects of heat stressed in tropic area. Med. Pet. 32: 155-161

Naas, I. A., C. E. B Romanini, D. P. Neves, G. R. Nascimento, \& R. A. Vercellino. 2010. Broiler surface temperature distribution of 42 day old chickens. Sci.Agric.(Piracicaba, Braz). 67: 497-502

North, M. O. \& D. D. Bell. 1990. Commercial Chicken Production Manual. Van Nostrand Reinhold, New York.

Pereira, D. F. \& I. A. Naas. 2008. Estimating the thermoneutral zone for broiler breeders using behavioral analysis. J. Comput Electron Agr. 62: 2-7. http://dx.doi.org/10.1016/ j.compag.2007.09.001

Quinteiro-Filho, W.M., A. Ribeiro, V. Ferraz-de-Paula, M. L. Pinheiro, M. Sakai, L. R. M. Sá, A. J. P. Ferreira, \& J. Pal-
ermo-Neto. 2010. Heat stress impairs performance parameters, induces intestinal injury, and decreases macrophage activity in broiler chickens. Poultry Sci. 89: 1905-1914. http://dx.doi.org/10.3382/ps.2010-00812

Sugito, W. Manalu, D. A. Astuti, E. Handharyani, \& Chairul. 2007. Heat stress effect and given of hexane jaloh (Salix tertasperma Roxb) to cortisol level, triiodothyrone and hematology profile of broiler chickens. JITV. 12:175-184

Van Brecht, A., H. Hens, \& J. L. Lemaire. 2005. Quantification of the heat exchange of chicken eggs. Poultry Sci. 84:353361. http://dx.doi.org/10.1093/ps/84.3.353

Versteeg, H. K. \& W. Malalasekera. 1995. An Introduction to Computational Fluid Dynamic The Finite Volume Method. Longman Scientific and Thechnical, Harlow.

Yahav, S., A. Straschnow, D. Luger, D. Shinder, J. Tanny, \& S. Cohen. 2004. Ventilation, sensible heat loss, broiler energy, and water balance under harsh environmental conditions. Poultry Sci. 83: 253-258. http://dx.doi.org/10.1093/ ps/83.2.253

Yanagi, T., Jr., H. Xin, \& R. S. Gates. 2001. Modeling partial surface evaporative cooling of chickens. Paper No. 01-3011 presented at Am. Soc. Agric. Eng. Mtg., Sacramento, CA.

Yani, A., H. Suhardiyanto, R. Hasbullah, \& B. P. Purwanto. 2007. Analisis dan simulasi distribusi suhu udara pada kandang sapi perah menggunakan Computational Fluid Dynamics (CFD). Med.Pet. 30: 218-228.

Yardimci, M. \& B. Kenar. 2008. Effect of stocking density on litter microbial load in broiler chickens. Arch Zootech. 11:7581. 